\title{
The Importance of First Semester Seminars for At-Risk First-Year Students: Analysis of Student Skills and Time Spent on Class Preparation
}

\author{
David E. Reed ${ }^{1, *(1)}$ and Guinevere Z. Jones ${ }^{2}$ \\ 1 Department of Environmental Science, University of Science and Arts of Oklahoma, \\ Chickasha, OK 73018, USA \\ 2 Department of Ecosystem Science and Management, University of Wyoming, Portland, OR 82001, USA; \\ gzjones13@gmail.com \\ * Correspondence: dreed@usao.edu
}

check for updates

Citation: Reed, D.E.; Jones, G.Z. The Importance of First Semester

Seminars for At-Risk First-Year Students: Analysis of Student Skills and Time Spent on Class Preparation. Educ. Sci. 2021, 11, 510. https:// doi.org/10.3390/educsci11090510

Academic Editor: Eleanor Dommett

Received: 13 July 2021

Accepted: 2 September 2021

Published: 6 September 2021

Publisher's Note: MDPI stays neutral with regard to jurisdictional claims in published maps and institutional affiliations.

Copyright: (c) 2021 by the authors. Licensee MDPI, Basel, Switzerland. This article is an open access article distributed under the terms and conditions of the Creative Commons Attribution (CC BY) license (https:// creativecommons.org/licenses/by/ $4.0 /)$.

\begin{abstract}
The high-school-to-college transition can be difficult as students are adapting to a multitude of academic and social changes simultaneously. The University of Wyoming has created a firstsemester program targeted at development of student skills for at-risk students using paired first-year seminar classes. Using student survey data from both pre- and post-course series, students were asked how important they thought academic and non-academic skills were as well as how much preparation time they were spending outside of class. Results from this work show large changes in the importance of skills and time spent studying during the transition from high school to college. This highlights the need to focus specifically on teaching skills to help students through the transition and suggests that not all skills are equal and data shows that students take longer than one semester to match their expected and actual amounts of time they spend outside of class studying.
\end{abstract}

Keywords: first year seminar; student skill development; student retention

\section{Introduction}

Much effort has been spent on improving first year retention rates and introductory level courses under the assumption that students are more likely to drop out of college or their chosen majors early in their degree progress [1]. Research historically and consistently indicates that thirty to fifty percent of all student withdrawals occur prior to their second year of college [2,3] and that first-semester GPA is a statistically linked to graduate rates [1]. According to Maisto and Tammi [4], student retention is important to colleges and universities since the pool of eligible college-aged students is decreasing and the cost of higher education is increasing [5]. However, research has shown that individual and institutional characteristics may have an impact on student retention [1,4,6-8].

Features that can affect college persistence and timing of attrition can be divided into pre-college and college factors. Pre-college factors can consist of attributes such as family income, religion, home-life characteristics, student demographics, parental demographics and education, and high school performance $[3,6,9,10]$. College variables for academic persistence can range from student community involvement such as living situation and involvement in campus life, to integration into the academic community that can consist of meeting with faculty, learning and balancing social skills, and dedicating an appropriate amount of time to coursework [10,11]. Both of these pre-college and college skillsets are critical to student success and students with under developed or lacking skills in either area can be at a higher risk for attrition [7,12]. A longitudinal study of first-generation college students showed that a specific focus on skill learning in their first-year lead to higher levels of achievement, however, this effect the impact of skill development was diminished as they moved closer to graduation, suggesting eventually, all students are developing skills throughout college [13]. 
At-risk students comprise a broad category, with a single or multiple reasons why a given student might be considered at-risk, and graduation rates for at-risk students are low $[14,15]$. Students are considered academically at-risk at the University of Wyoming based on low high school GPA or ACT scores; this group of students represents larger amounts of minority, low-income, and first generation students than the general student body at the University of Wyoming [10]. A study by Laskey and Hetzel [16] shows that the pre-college factor of student personality was significantly linked to retention and academic success for at-risk students. With so many factors going into student success, it is important to remember that both student populations and colleges are always changing [17].

For this population of conditionally admitted students at the University of Wyoming, an academic support program is available for them, called the Synergy Program. The Synergy Program enrolls approximately 144 students each year and offers first-year seminar courses as a requirement of conditional admission with either a STEM (Science, Technology, Engineering and Math) or non-STEM (usually Humanities) theme. The majority of the Synergy students choose their seminar course based on personal interest.

The Synergy Program at the University of Wyoming promotes academic success and retention for underprepared and at-risk students by creating a series of first semester curricula as theme-based college transition skills courses that are paired with English courses that focus on college level writing skills. This creates a cohort group of courses for the students with increased communication between instructors at the same time allowing greater development of student social networks (Figure 1). Creating both academic and social networks by design helps to promote student engagement during the critical first weeks [18] and first semester [19,20].

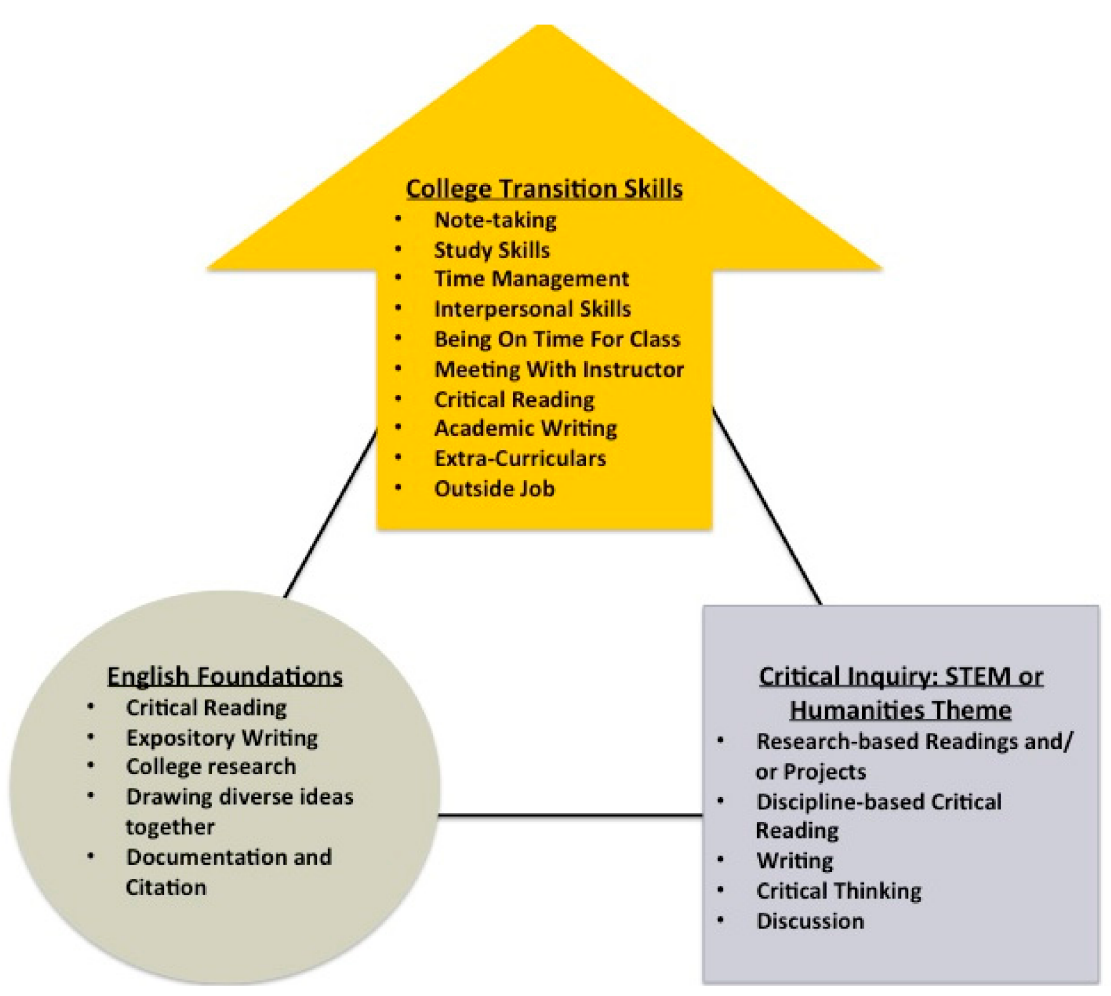

Figure 1. A conceptual overview of the University of Wyoming's Synergy Program.

College transition skills are often a focus in first-year seminar courses and college academic success and persistence has been linked to first-year seminar courses [12,21]. In the University of Wyoming Synergy program these core skills are emphasized prior to the start of the first semester, and again throughout the semester in the seminar course. Skills that are often discussed and taught in these seminar courses are note-taking, study skills, time management, interpersonal skills, punctuality, meeting with the instructor, critical 
reading, academic writing, the importance of extra-curricular activities, and managing an outside job.

In this study we investigate the self-reported results by first-year, academically at-risk students in the University of Wyoming Synergy program by asking the following questions: (1) What skills do students self-identify as important for college success and how do those skills improve from high school through their first two semesters of college? (2) How much time do students spend on academic work from high school through their second semester of college? The purpose of this paper is to highlight underprepared first-year student perceptions of both the skills needed and the amount of time outside of the classroom that are necessary to be a successful student as well as to supply data-driven results for instructors and administrators of first-semester or first-year programs.

\section{Methods}

During the fall 2012 semester, we developed anonymous pre- and post-course surveys which asked students how much time they spent on various academic tasks such as preparing for class and participating in co-curricular actives, as well as what skills they consider most critical for academic success. The pre-course survey asked them to respond based on their time in high school and their expected tasks and skills during their first semester, while the post-course survey asked students to respond reflecting upon their first semester and looking forward to their second semester. Pre-course surveys were administered within the initial 2-weeks of the semester, in class with the course instructor not present. Post-course surveys were web-based and completed within the final 3-weeks of their first semester. Follow-up surveys tracked the same queries for students who persisted at the University of Wyoming to their junior and senior years and were communicated via email. All students were given an "opt-out" choice and their responses are anonymous to their instructor and peers. Course surveys are included as a Supplementary File.

Full-time, first-year students were asked to take the voluntary survey in all seven Synergy courses offered during the fall 2012 term. A total of 154 students completed the pre-course survey while 129 students completed the post-course survey. A total of 112 students completed both surveys and only data from students that only completed each survey was included in the analysis. Responses were analyzed for significance using a paired $t$-test using R. Significance was determined when paired $t$-test $p$-values were less than 0.05 .

\section{Results}

\subsection{Student Skills}

Students self-identified several academic skills to be most important, including notetaking, study skills, and time management. Regardless of the time period (high school, first college semester or second college semester) they were asked to consider, these skills were noted as being more important for college success relative to other skills on the surveys, however the note-taking, study skills, and time management skills also showed an increase from high school to college. At the transition between high school and the first semester of college, the importance of academic skills increased $(p<0.05)$, namely meeting with the instructor and critical reading. Students responded that interpersonal skills, extracurricular activities and having a job outside of class were less important coming from high school. The only two skills that were rated the same were being on time for class and academic writing (Figure 2 (top panel)). 


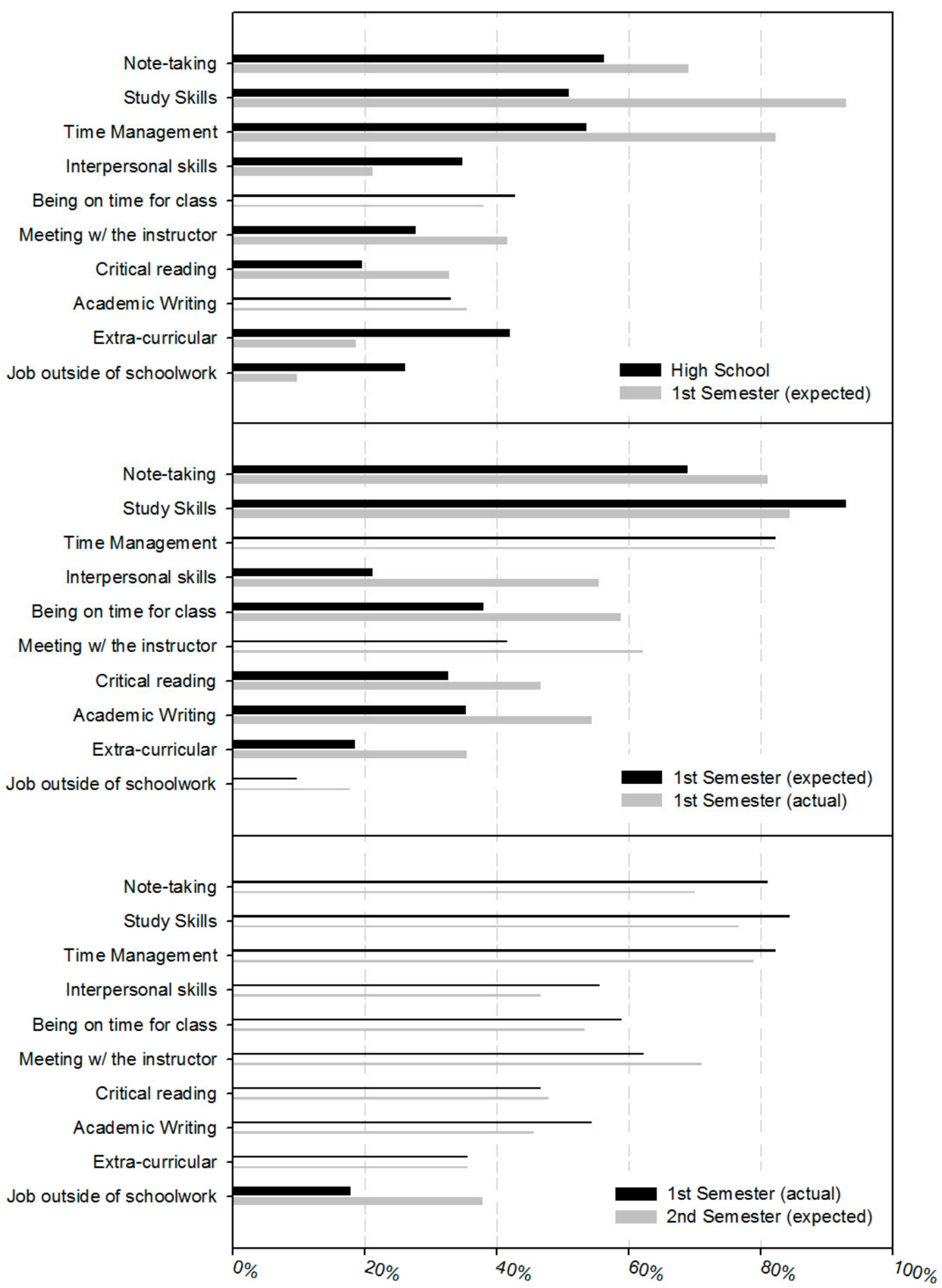

Figure 2. Student skills self-selected as important. Top panel: Student-reported high school skills from pre-survey in dark grey and 1st semester expected skills from pre-survey in light grey. Significant differences $(p<0.05)$ are indicated by thick bars. Middle panel: Student-reported expected 1st semester skills from pre-survey in dark grey and 1st semester actual Scheme 0. are indicated by thick bars. Bottom panel: Student-reported 1st semester skills from post-survey in dark grey and expected 2nd semester skills from post-survey in light grey. Significant differences $(p<0.05)$ are indicated by thick bars.

Results from expected skills needed in their first semester were compared to skills reported being important for the first semester in hindsight from the post-course survey in Figure 2 (middle panel). For most skills, the students had a significantly lower opinion $(p<0.05)$ of what they thought they needed at the start of the semester as compared to their reflection at the end of the semester. The skills that were statistically the same between first semester expectations and reality are time management, critical reading, and having an outside job. Notably, interpersonal skills more than doubled from what was thought to be important to what actually was important during the first semester. 
At the end of their first semester, when asked to look ahead to their second semester of college, students ranked all classroom skills the same. However, the students placed more value on having an outside job for the second semester (Figure 2 (bottom panel)).

\subsection{Student Time Spent Preparing for Class}

Going into their first semester of college and reflecting on their time in high school, most students reported significantly $(p<0.05)$ less time spent outside of class on coursework than they expected to spend in college. (Figure 3 (top panel)), with the high school distribution data skewed towards the low end of the scale (zero and 1-5) while the expected time spent in the first semester was higher in the upper ranges (11-15 and 16-20). In the middle (6-10) and at the very upper ranges of time (21-25, 26-30, 30+ hours per week) there was no significant difference $(p>0.05)$ between the responses for what students spent in high school and what they expected to spend during their first semester.

There were statistically significant differences $(p<0.05)$ for the majority of time blocks between what students expected to spend during their first semester and what they reported to actually spend (Figure 3 (middle panel)). Similar to high school, they expected to spend more time studying than what they actually did, with zero and 1-5 being lower in reality and 6-10, 11-15 and 16-20 all being expected to be higher. Again, the very upper ranges of time (21-25, 26-30, 30+ hours per week) had no significant difference $(p>0.05)$ between the responses.

At the end of their first semester, when asked to look forward to their second semester, students once again expected to spend more time studying outside of the classroom (Figure 3 (bottom panel)). A similar pattern of students' actual time spent studying in their first semester compared to what they expected for their second was noted in the zero and 1-5 blocks, while the 6-10, 11-15 and 16-20 blocks again were all expected to be higher. Additionally expected to be higher in the second semester was one block (26-30) in the very upper ranges.

Results not shown in Figure 3 include a slight lowering of expected amounts of time studying going from how much time students expect to study their first semester compared to their second semester. This was statistically significant $(p<0.05)$ at the $6-10$ and 16-20 time blocks. 


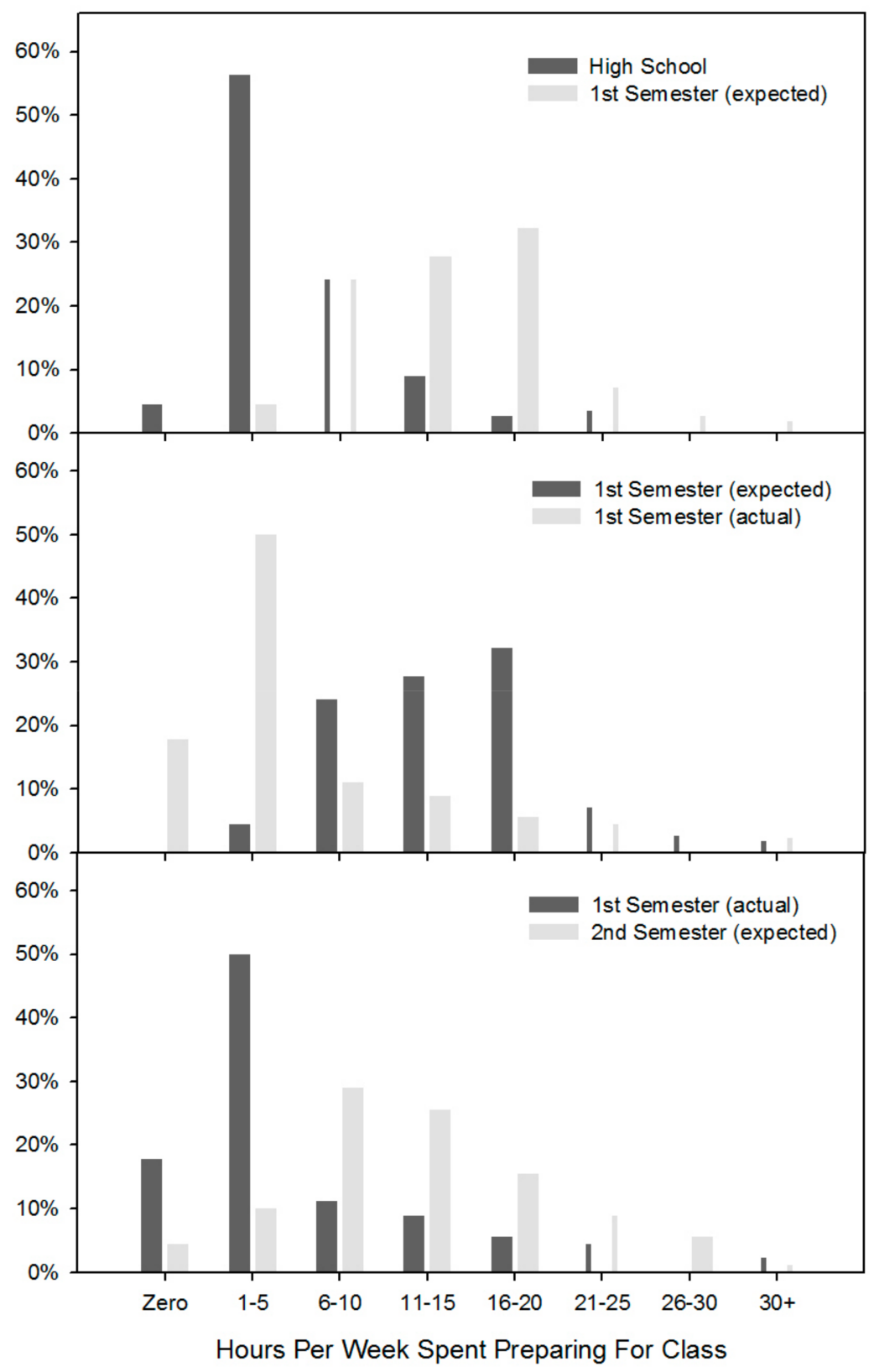

Figure 3. Time spent outside of the classroom per week for course preparation. Top panel: Studentreported high school time from pre-survey in dark grey and 1st semester expected time spent from pre-survey in light grey. Significant differences $(p<0.05)$ are indicated by thick bars. Middle panel: Student-reported expected 1st semester time from pre-survey in dark grey compared to 1st semester actual time from post-survey in light grey. Significant differences $(p<0.05)$ are indicated by thick bars. Bottom panel: Student-reported time needed for the 1st semester from post-survey in dark grey and expected time needed for 2 nd semester from post-survey in light grey. Significant differences $(p<0.05)$ are indicated by thick bars.

\section{Discussion}

To address the first question of what skills students self-identified as important, results from student surveys at both the start and the end of the first semester found the traditional college skills of note-taking, study skills and time management as being more important than any other skill. Study skills have previously been shown to be positively correlated with academic success $[7,22]$, but this work shows a broader set of skills are required. Students largely are correct when they expect these skills to be more important in college, 
but the skills were still ranked the highest skills in high school as well. One explanation for this difference is that students have a good understanding of skills that cut across all college disciplines; however a similar level of importance is not shown for being on time to class and meeting with the course instructor. It is also possible that the note-taking, study skills and time management skills are more ingrained at the high school level, and so students expect them to still be important, while being on time to class and meeting with the instructor outside of class often are new skills for college students.

Time management skills can often be difficult to teach but worthwhile for the student [23]. In discussions with other instructors within the Synergy Program, we found a wide range of times when that skill would be emphasized during the semester. These discussions brought out a "Goldilocks" idea that time management is best taught at some point in the middle of the semester. Too early and students feel confident in their abilities to handle their time, since relatively little is being asked of them, and too late in the semester and much of the semester could be wasted for students that are struggling with time management. At some point in time, generally after the first set of exams, we found students were starting to struggle with completing assignments and felt ready to critically discuss their own time management skills. Particular emphasis on time management being a skill that is never mastered and only incrementally improved was also found to be useful as a teaching method.

Interpersonal skills showed the largest jump in importance after the first semester after being the only academic skill to decrease in importance from high school, showing that students realize how important social-based actions (e.g., social study groups, help getting notes when missing class, keeping balance between studying and life) can be in college as compared to their first impressions of college. The work of Entwistle and Entwistle [7] shows a connection between introverted personalities and academic achievement, so while the students had less of an emphasis on interpersonal skills, there can be a benefit for extroverted students to form peer-group relationships. More recent results from SavitzRomer, Rowan-Kenyon [22] show that interpersonal and social skills are often less likely to be the focus of academic support programs, and conclude the institutions may assume students will learn these skills on their own. Out of class activities during the first college semester program helped students get to know each other and there is often just as much of a social transition as there is an academic transition for first semester students. These social skills are frequently learned regardless of the amount of academic time spent on them, but results from this work highlight how much students grow socially their first semester.

Perhaps similar to social skills, extra-curricular activities are expected to be less important coming out of high school than what the student ended up thinking at the end of the first semester. Again, while not found directly in first semester syllabi, students having the skillset to be able to successfully balance in- and out-of-class academic and social activities is ultimately important for student success.

After the learning curve of the first semester of college, students have generally practiced and improved what skills are needed for their future college semester, and previous work has shown this first semester academic success to be critical for likelihood of graduation [1]. Only at this point does the importance of having a job outside of the classroom show up as a significant increase $(p<0.05)$, hypothesized to be correlated with seeing the true cost of attending college as well as incremental increase in time management skills. Employment has been shown to be more likely for low-income students, and students working more than $20 \mathrm{~h}$ per week are more likely to leave college during the first year [24].

To address the second question of this work, the survey replies asking how much time students spend on preparing for class show a large difference between expectations of how much time will be required and their actual time commitment to academic activities. This is similar to their assessment of skills coming out of high school and starting college, but while expected and actual importance of skills begin to align after one semester, the difference in expected and actual time spent studying does not. At the end of their first semester, students still expect to study more their second semester than they did in their 
first semester, at a rather large average amount of 10+ hours a week. A recent meta-analysis shows student self-efficacy and motivation as the best predictors of achievement and persistence [6], and we think this effect is known by students as they feel like they need to spend more time than what is really needed.

It should be noted that the actual time spent studying increased from their high school levels and their expected time needed does go down, and it is possible that how much time students feel like they should be studying and the actual amount of studying will align over the course of their entire college career. The cause of this difference is potentially rooted in how students culturally view college, where they've been told it will require significantly more time than high school, but this data suggests it takes longer than one semester for students to match their expectations to reality. Adding to that, some courses that students take their first semester can be less demanding of their time, as compared to upper level courses. We conclude that students, by and large, have a good understanding of how much time it takes to be successful college students, but it takes more than one semester to build up to the level of work needed to be successful college students.

Taken again from discussions with the other instructors within the program, we found that having high level of academic skills were often more important to students then simply spending time outside of the classroom studying. In fact, spending too much time studying often highlighted a relatively lacking skillset; e.g., poor note taking requiring students to first copy other student notes before working on assignments, distracted studying and low time management skills causes wasted hours, or spending a large amount of time working while confused instead of a quick meeting with the instructor to clear up the point of confusion. We found that some students can think that spending a large amount of time alone is enough, while the most successful students tend to either focus on learning skills or already show a high level of competence in their skillset. On the surface, this finding could be contradictory to the grit theory of student performance $[25,26]$ where self-motivation is more a factor of performance than student IQ. Personality traits including self-motivation and self-discipline has been suggested by many to lead to high academic achievement, but while students need to be self-motived, they also need to have the correct academic skills in place in order to be successful. Here, for first-year, at-risk students, instructors in these first-year seminar courses have anecdotally found successful students to be focused on skill development.

\section{Conclusions}

During the critical first semester of college, students are asked to balance a multitude of responsibilities. Working on building the skills needed by students, both academic and social, while managing their time, is difficult and can be overlooked in first semester courses. While this study only used student survey data and did not track student success beyond their first year, this study still provides key insight into the college transition process. We believe that working to develop skills can make a significant difference in students' ability to succeed in college, regardless of their apparent struggles with implementing skills immediately. Going forward, we suggest additional studies on the relative importance of academic skills by connecting student skills to GPA or retention rates.

A first-year program targeting transition skills should communicate and take measures to address the large gap in expectations and actual behaviors that contribute to academic success. Both academic and social skills should be discussed and emphasis should be placed on incremental improvement. Learning and developing skills is a lifelong process and will last well beyond college. Students need to understand that skill development is an on-going and challenging endeavor-not a quick turn-around. Instructors of first year seminars should be mindful that not all academic skills are equal and that students adjust to college over a longer period of time then the first weeks of their first year.

Supplementary Materials: The following are available online at https:/ /www.mdpi.com/article/10 .3390/educsci11090510/s1. Survey S1: Synergy Program Student Survey. Fall 2012 Pre-Survey. 
Author Contributions: Conceptualization, D.E.R. and G.Z.J.; methodology, D.E.R.; software, D.E.R.; formal analysis, D.E.R.; writing-original draft preparation, D.E.R.; writing-review and editing, D.E.R. and G.Z.J. All authors have read and agreed to the published version of the manuscript.

Funding: This research was funded by Wyoming NASA Space Grant Consortium, the University of Wyo-ming Program in Ecology teaching fellowship program and the National Science Foundation (NSF) Atmospheric and Geospace Sciences Postdoctoral Fellowship Program (\#GEO-1430396).

Institutional Review Board Statement: The study was conducted according to the guidelines of the Declaration of Helsinki, and approved by the Institutional Review Board of the University of Wyoming (Expedited Review / Approval on 2 October 2012).

Informed Consent Statement: Informed consent was obtained from all subjects involved in the study.

Data Availability Statement: Data is available upon request to the authors.

Conflicts of Interest: The authors declare no conflict of interest.

\section{References}

1. Gershenfeld, S.; Ward Hood, D.; Zhan, M. The Role of First-Semester GPA in Predicting Graduation Rates of Underrepresented Students. J. Coll. Stud. Retent. Res. Theory Pract. 2016, 17, 469-488. [CrossRef]

2. Summerskill, J. Dropouts from College. In The American College: A Psychological and Social Interpretation of the Higher Learning; John Wiley \& Sons Inc.: Hoboken, NJ, USA, 1962.

3. Murtaugh, P.A.; Burns, L.D.; Schuster, J. Predicting the retention of university students. Res. High. Educ. 1999, 40, 355-371. [CrossRef]

4. Maisto, A.; Tammi, M. The effect of a content-based freshman seminar on academic and social integration. J. First-Year Exp. Stud. Transit. 1991, 3, 29-47.

5. Pike, G.R.; Graunke, S.S. Examining the Effects of Institutional and Cohort Characteristics on Retention Rates. Res. High. Educ. 2015, 56, 146-165. [CrossRef]

6. Robbins, S.B.; Lauver, K.; Le, H.; Davis, D.; Langley, R.; Carlstrom, A. Do Psychosocial and Study Skill Factors Predict College Outcomes? A Meta-Analysis. Psychol. Bull. 2004, 130, 261-288. [CrossRef]

7. Entwistle, N.J.; Entwistle, D. The Relationships between Personality, Study Methods and Academic Performance. Br. J. Educ. Psychol. 1970, 40, 132-143. [CrossRef]

8. Kerby, M.B. Toward a New Predictive Model of Student Retention in Higher Education: An Application of Classical Sociological Theory. J. Coll. Stud. Retent. Res. Theory Pract. 2015, 17, 138-161. [CrossRef]

9. LaRose, S.; Boivin, M. Attachment to Parents, Social Support Expectations, and Socioemotional Adjustment During the High School-College Transition. J. Res. Adolesc. 1998, 8, 1-27. [CrossRef]

10. Heaney, A.; Fisher, R. Supporting Conditionally-Admitted Students, A Case Study of Assessing Persistence in a Learning Community. J. Scholarsh. Teach. Learn. 2011, 11, 62-78.

11. Larose, S.; Bernier, A.; Tarabulsy, G.M. Attachment State of Mind, Learning Dispositions, and Academic Performance During the College Transition. Dev. Psychol. 2005, 41, 281-289. [CrossRef] [PubMed]

12. Hyers, A.; Joslin, M. The First Year Seminar as a Predictor of Academic Achievement and Persistence. J. First-Year Exp. Stud. Transit. 1998, 10, 7-30.

13. Wibrowski, C.R.; Matthews, W.K.; Kitsantas, A. The Role of a Skills Learning Support Program on First-Generation College Students' Self-Regulation, Motivation, and Academic Achievement, A Longitudinal Study. J. Coll. Stud. Retent. Res. Theory Pract. 2016, 19, 317-332. [CrossRef]

14. Carey, K. A Matter of Degrees: Improving Graduation Rates at Four-Year Colleges and Universities; The Education Trust: Washington, DC, USA, 2004.

15. Horton, J. Identifying at-risk factors that affect college student success. Int. J. Process Educ. 2015, 7, 83-101.

16. Laskey, M.L.; Hetzel, C.J. Investigating Factors Related to Retention of At-Risk College Students. Learn. Assist. Rev. 2011, 16, 31-43.

17. Barbera, S.A.; Berkshire, S.D.; Boronat, C.B.; Kennedy, M.H. Review of Undergraduate Student Retention and Graduation Since 2010, Patterns, Predictions, and Recommendations for 2020. J. Coll. Stud. Retent. Res. Theory Pract. 2017, 22, 227-250. [CrossRef]

18. Woosley, S.A. How important are the first few weeks of college? The long term effects of initial college experiences. Coll. Stud. J. 2003, 37, 201-208.

19. Kuh, G.D. Student engagement in the first year of college. In Challenging and Supporting the First-Year Student: A Handbook for Improving the First Year of College; Wiley: Hoboken, NJ, USA, 2005; pp. 86-107.

20. Kuh, G.D.; Cruce, T.M.; Shoup, R.; Kinzie, J.; Gonyea, R.M. Unmasking the effects of student engagement on first-year college grades and persistence. J. High. Educ. 2008, 79, 540-563. [CrossRef]

21. Hansen, M.J.; Schmidt, L. The Synergy of and Readiness for High-Impact Practices During the First Year of College. J. First-Year Exp. Stud. Transit. 2017, 29, 57-82. 
22. Savitz-Romer, M.; Rowan-Kenyon, H.T.; Fancsali, C. Social, Emotional, and Affective Skills for College and Career Success. Change. Mag. High. Learn. 2015, 47, 18-27. [CrossRef]

23. Grissom, J.A.; Loeb, S.; Mitani, H. Principal time management skills, Explaining patterns in principals' time use, job stress, and perceived effectiveness. J. Educ. Adm. 2015, 53, 773-793. [CrossRef]

24. Bozick, R. Making It through the First Year of College, The Role of Students' Economic Resources, Employment, and Living Arrangements. Sociol. Educ. 2007, 80, 261-284. [CrossRef]

25. Duckworth, A.L.; Peterson, C.; Matthews, M.D.; Kelly, D.R. Grit: Perseverance and passion for long-term goals. J. Personal. Soc. Psychol. 2007, 92, 1087-1101. [CrossRef] [PubMed]

26. Duckworth, A.L.; Seligman, M.E. Self-Discipline Outdoes IQ in Predicting Academic Performance of Adolescents. Psychol. Sci. 2005, 16, 939-944. [CrossRef] [PubMed] 